(C) 2020, The Authors. Published by Elsevier Inc. and Fass Inc. on behalf of the American Dairy Science Association ${ }^{\circledR}$. This is an open access article under the CC BY-NC-ND license (http://creativecommons.org/licenses/by-nc-nd/4.0/).

\title{
Comparative analysis of the skim milk and milk fat globule membrane proteomes produced by Jersey cows grazing pastures with different plant species diversity
}

\author{
R. A. Scuderi, ${ }^{1}$ Y..W. Lam, ${ }^{2}$ D. B. Ebenstein, ${ }^{1}$ R. Tacoma, ${ }^{1}$ L. M. Cersosimo, ${ }^{1 *}$ J. Kraft, ${ }^{1}$ A. F. Brito, ${ }^{3}{ }^{\oplus}$ \\ and S. L. Greenwood ${ }^{1}+$ (i) \\ ${ }^{1}$ Department of Animal and Veterinary Sciences, The University of Vermont, Burlington 05405 \\ ${ }^{2}$ Vermont Genetics Network Proteomics Facility, The University of Vermont, Burlington 05405 \\ ${ }^{3}$ Department of Agriculture, Nutrition, and Food Systems, The University of New Hampshire, Durham 03824
}

\begin{abstract}
The objective of this experiment was to identify and characterize the bovine milk proteome within the skim milk fraction and milk fat globule membrane (MFGM)-associated fraction from 16 organically certified lactating Jersey cows after a short term of grazing pastures with or without annual forage crops (AFC). Cows were offered a partial mixed ration $(\sim 60 \%$ of dry matter intake) and approximately $40 \%$ of their total dry matter intake as herbage. Eight cows were offered a cool-season grass-legume herbage (GLH), which included orchardgrass (Dactylis glomerata), timothy (Phleum pratense), Kentucky bluegrass (Poa pratensis), and white clover (Trifolium repens). The other 8 cows were offered the same GLH strip-tilled with the AFC, including oat (Avena sativa), millet (Pennisetum glaucum), teff (Eragrostis tef), buckwheat (Fagopyrum esculentum), and chickling vetch (Lathyrus sativus). Milk samples were collected from each cow during a.m. and p.m. milkings on d 19 to 21 of grazing, and composite milk samples per cow were analyzed for (1) the high-abundance milk protein profile, $(2)$ the skim milk low-abundance protein-enriched proteome, and (3) the MFGM proteome. Of the 443 proteins identified in the skim and MFGM proteomes, 433 were included in statistical analysis, including 68 proteins identified in the skim milk fraction and 365 in the MFGM-associated fraction. Analysis of the skim and MFGM proteomes encompassed unique gene ontology profiles and proportions of functional classifications. In response to diet, $\alpha_{\mathrm{S1}}$-casein as well as 8 low-abundance proteins were present in higher concentration or abundance in milk
\end{abstract}

Received October 9, 2019.

Accepted March 17, 2020.

*Current address: Department of Animal Sciences, University of Florida, Gainesville 32608.

†Corresponding author: sabrina.greenwood@uvm.edu from cows grazing the GLH strip-tilled with the AFC compared with milk from cows grazing GLH, suggesting that even short-term grazing of pastures including some AFC may affect the milk proteome.

Key words: alternative forage crop, milk proteomics, liquid chromatography-tandem mass spectrometry, gene ontology

\section{INTRODUCTION}

The bovine milk proteome encompasses a broad array of proteins and is understood to be important in calf and human nutrition due to its bioactive profile (Vargas-Bello-Pérez et al., 2019). Bovine milk comprises high-abundance proteins, including caseins, $\alpha$-LA, and $\beta-\mathrm{LG}$, as well as thousands of low-abundance proteins (D'Amato et al., 2009). As outlined by Shennan and Peaker (2000), milk proteins can be transported and secreted into the alveolar or ductal lumen via several routes, including transport by the Golgi apparatus, secretion as a component of the milk fat globule membrane (MFGM) or within a cytosolic crescent captured within a milk fat droplet, transcytotic transport involving organelle participation, or direct paracellular transport of proteins from the interstitial fluid to milk. The proportional contribution of these routes toward creation of the resulting milk proteome secreted by the cow appears to be affected by numerous factors, including stage of lactation (Wall et al., 2015), hormonal status (Stelwagen and Singh, 2014), and mammary inflammation, including mastitis (Wellnitz et al., 2016).

The skim fraction of the secreted milk contains an array of biologically active proteins (Greenwood and Honan, 2019). The MFGM is another protein-containing fraction that contains a rich bioactive profile (Lee et al., 2018). Butyrophilin (BTN), for example, is a common MFGM-associated protein that is a member of the Ig superfamily and is involved in immune $\mathrm{T}$ cell responses (Demmelmair et al., 2017). The MFGM is integral and correlated with milk fat secretion; thus, 
it is feasible that increases in milk fat output could increase the abundance of bioactive proteins and peptides in milk.

Inclusion of herbage and alternative forages such as annual crops or non-alfalfa legumes in the diet, particularly in pasture-based diets, are known to affect milk yield and milk composition, particularly milk fat content, even after only a short term of grazing the alternative pasture (Christian et al., 1999; Totty et al., 2013; Bryant et al., 2018). The inclusion of annual forage crops (AFC) in grazing pastures is increasing in popularity in the United States as a method to effectively increase pasture biomass when cool-season grass growth is limited in the summer months (Juntwait et al., 2016). Many of these AFC have unique nutrient profiles, often including secondary compounds that affect animal metabolism and milk production (Totty et al., 2013; Bryant et al., 2018). Given that the inclusion of AFC in pasture can affect milk production and general milk composition produced by grazing dairy cattle and that inclusion of plant-based secondary compounds, such as condensed tannins, in the diet of lactating dairy cattle can affect the skim milk proteome (Scuderi et al., 2019), it is feasible that inclusion of AFC in grazing diets could alter the skim milk- or MFGM-associated proteomes.

To date, very few studies have investigated the effect of pasture profile on the milk proteome produced by grazing cattle. It is hypothesized that the inclusion of AFC in pastures will alter the skim- and MFGMassociated proteomes produced by cattle grazing these pastures as part of their daily ration over a short-term grazing period in the summer. The objectives of this study were to use proteomic approaches to characterize the skim milk- and MFGM-associated milk proteomes produced by cows grazing cool season grass-legume herbage (GLH) or GLH strip-tilled with AFC (GLAH) during the summer.

\section{MATERIALS AND METHODS}

The University of New Hampshire Institutional Animal Care and Use Committee approved all experimental procedures (IACUC no. 150302). The experiment was carried out at the University of New Hampshire Burley-Demeritt Organic Dairy Research Farm (Lee, $\mathrm{NH} ; 43^{\circ} 10^{\prime} \mathrm{N}, 70^{\circ} 99^{\prime} \mathrm{W}$ ) from July 14 to August 2, 2015.

\section{Animals, Design, and Diets}

A subset of 16 (12 multiparous and 4 primiparous) organically certified Jersey cows that were part of a larger study (Juntwait et al., 2016) were included in the current study. Animal number was determined to be appropriate by calculation of a power statistic at $80 \%$ power accounting for a $50 \%$ coefficient of variation and $80 \%$ treatment difference, which was based on changes in abundance of milk BTN subfamily 1 member A1 due to low-level grape marc supplementation to dairy cattle by Scuderi et al. (2019). At the beginning of the study, cows (143 \pm 58 DIM) were producing (mean \pm standard deviation) $18.1 \pm 3.9 \mathrm{~kg}$ of milk/d. Cows were milked twice daily (0530 and $1630 \mathrm{~h}$ ) throughout the trial. Cows were blocked by milk yield, DIM, and parity and then assigned to treatments according to a randomized complete block design with $14 \mathrm{~d}$ for diet adaptation followed by $7 \mathrm{~d}$ for data and sample collection. Animals were fed a partial TMR at $60 \%$ of their daily DMI comprising (as \% of DM) 19.9\% ADF, $32.8 \%$ NDF, $15.2 \%$ CP, $23.8 \%$ starch, $6.4 \%$ crude fat, $3.1 \%$ lignin, and $8.0 \%$ ash as outlined by Juntwait et al. (2016). For the remaining $40 \%$ of daily DMI, cows grazed GLH. At the onset of the trial, 8 cows continued to graze a GLH pasture that consisted of orchardgrass (Dactylis glomerata), timothy (Phleum pratense), Kentucky bluegrass (Poa pratensis), and white clover (Trifolium repens). The other 8 cows grazed GLAH, including oat (Avena sativa), millet (Pennisetum glaucum), teff (Eragrostis tef), buckwheat (Fagopyrum esculentum), and chickling vetch (Lathyrus sativus). All cows had access to their assigned pastures from $1800 \mathrm{~h}$ (after evening milking) to $0500 \mathrm{~h}$ the following morning in a strip grazing management system. Pastures were sampled weekly throughout the trial, and samples were taken at 10 random sites within each paddock on each sampling day. Pre-grazed pasture samples were clipped within a measured quadrat at approximately $7 \mathrm{~cm}$ from ground height for botanical composition, nutrient profile, and biomass measurements. Biomass measurements were completed on both pre- and post-grazed pasture areas. The herbage nutrient compositions, herbage biomass yield, and botanical composition of the GLH and GLAH pastures were reported previously by Juntwait et al. (2016). Briefly, the botanical composition (DM basis) for the GLH pastures averaged $69 \%$ grasses, $11 \%$ legumes, and $20 \%$ other (broadleaf, weeds, and dead), with a nutrient composition (as \% of DM) of $35.0 \% \mathrm{ADF}, 53.1 \% \mathrm{NDF}, 12.9 \% \mathrm{CP}, 1.0 \%$ starch, $5.2 \%$ crude fat, $4.3 \%$ lignin, and $7.8 \%$ ash. The botanical composition (DM basis) of the GLAH pastures averaged $61 \%$ grasses, $13 \%$ legumes, $1 \%$ AFC grasses, $2 \%$ AFC legumes, $12 \%$ AFC broadleaf, and $11 \%$ other (non-AFC broadleaf, weeds, and dead). The nutrient composition of the GLAH pasture was (as \% of DM) $38.8 \%$ ADF, $50.1 \%$ NDF, $14.8 \%$ CP, $2.2 \%$ starch, $5.0 \%$ crude fat, $9.1 \%$ lignin, and $6.2 \%$ ash. 


\section{Sampling}

Concurrent with forage sampling days, individual milk samples were collected on d 19 to 21 of the experiment from each milking for 4 consecutive milkings (d 19 p.m. milking, d 20 a.m. and p.m. milkings, and d 21 p.m. milking) and analyzed for protein percentage, fat percentage, lactose percentage, and urea- $\mathrm{N}$ as outlined by Juntwait et al. (2016). Milk production and composition results for each of the 16 cows included in this study were analyzed using statistical methods outlined below and are listed in Table 1. In addition, 3 milk subsamples were collected at each of these 4 consecutive milkings from each individual cow, flash frozen immediately after collection in a dry ice ethanol bath, and transported on dry ice to the University of Vermont (Burlington, VT) for analysis. At each sample collection, 3 subsamples were collected for each cow: 1 subsample $(\sim 15 \mathrm{~mL})$ was collected for HPLC quantification of high-abundance proteins and was stored at $-20^{\circ} \mathrm{C}$, whereas the 2 other subsamples $(\sim 100 \mathrm{~mL}$ total each) were collected for MS (liquid chromatographytandem MS; LC-MS/MS) based proteomic profiling of the low-abundance proteins in the skim milk and MFGM fractions and were stored at $-80^{\circ} \mathrm{C}$ until further analysis.

\section{HPLC Quantification of High-Abundance Milk Proteins}

Milk samples collected for HPLC analysis were thawed overnight at $4^{\circ} \mathrm{C}$, pooled within cow according to milk yield to create 1 representative sample per cow $(\mathrm{n}=16$ samples total $)$, and centrifuged at $4,000 \times g$ for 10 min at $4^{\circ} \mathrm{C}$. The skim milk was then prepared and analyzed as previously described (Tacoma et al., 2016), and the fat content of these samples was assumed to be in trace amounts.

\section{Preparation of the Low-Abundance Protein-Enriched Skim Milk Fraction}

Subsamples collected for LC-MS/MS skim protein analysis were pooled within cow according to milk yield, creating 1 representative sample per cow $(\mathrm{n}=$ 16 samples total). Additionally, a universal control was generated by pooling milk from each GLH cow according to milk yield, which was subsequently used to compare relative-fold abundance changes in proteins across all samples. Composite samples from each cow, as well as the universal control, were fractionated, enriched, digested, labeled with isobaric tandem mass tags (TMT; Thermo Fisher Scientific, Waltham, MA), and analyzed according to established methods as previously reported (Tacoma et al., 2017b). Two 9-plexes were generated in this experiment, each including the universal control and a random subset of 8 samples. The two 9-plexes were then submitted for LC-MS/MS analysis as previously described (Tacoma et al., 2017b).

\section{Isolation of the MFGM-Associated Protein Fraction}

The third set of subsamples collected for protein profiling in the MFGM fraction was thawed overnight at

Table 1. Milk yield and components from cows that grazed either a grass-legume herbage (GLH) or pastures that included GLH plus annual forage crops (GLAH)

\begin{tabular}{|c|c|c|c|}
\hline \multirow[b]{2}{*}{ Item } & \multicolumn{2}{|c|}{ Diet $^{1}$} & \multirow[b]{2}{*}{$P$-value } \\
\hline & GLH & GLAH & \\
\hline Milk yield $(\mathrm{kg} / \mathrm{d})$ & $17.31 \pm 0.84$ & $18.90 \pm 0.84$ & 0.20 \\
\hline ECM yield ${ }^{2}(\mathrm{~kg} / \mathrm{d})$ & $19.35 \pm 1.00$ & $22.87 \pm 1.00$ & 0.03 \\
\hline Milk solids yield ${ }^{3}(\mathrm{~kg} / \mathrm{d})$ & $2.16 \pm 0.11$ & $2.53 \pm 0.11$ & 0.03 \\
\hline Milk lactose $(\%)$ & $4.79 \pm 0.03$ & $4.80 \pm 0.03$ & 0.77 \\
\hline Milk lactose yield $(\mathrm{kg} / \mathrm{d})$ & $0.83 \pm 0.04$ & $0.91 \pm 0.04$ & 0.19 \\
\hline Milk fat (\%) & $4.29 \pm 0.12$ & $4.86 \pm 0.12$ & 0.01 \\
\hline Milk fat yield $(\mathrm{kg} / \mathrm{d})$ & $0.74 \pm 0.04$ & $0.92 \pm 0.04$ & 0.02 \\
\hline Milk protein $(\%)$ & $3.43 \pm 0.08$ & $3.72 \pm 0.08$ & 0.02 \\
\hline Milk protein yield $(\mathrm{kg} / \mathrm{d})$ & $0.59 \pm 0.03$ & $0.70 \pm 0.03$ & 0.02 \\
\hline \multicolumn{4}{|c|}{ Milk protein ( $\mathrm{mg} / \mathrm{mL}$ of skim milk $)$} \\
\hline$\kappa-\mathrm{CN}$ & $7.37 \pm 0.04$ & $8.49 \pm 0.04$ & 0.06 \\
\hline$\alpha_{\mathrm{S}^{2}} \mathrm{CN}$ & $1.50 \pm 0.09$ & $1.43 \pm 0.09$ & 0.56 \\
\hline$\alpha_{\mathrm{S}_{1}}-\mathrm{CN}$ & $12.17 \pm 0.46$ & $14.35 \pm 0.46$ & 0.01 \\
\hline$\beta-\mathrm{CN}$ & $13.53 \pm 0.32$ & $14.43 \pm 0.32$ & 0.07 \\
\hline$\alpha-\mathrm{LA}$ & $1.00 \pm 0.05$ & $1.00 \pm 0.05$ & 1.00 \\
\hline$\beta$-LG variant B & $1.97 \pm 0.45$ & $2.10 \pm 0.45$ & 0.85 \\
\hline$\beta-\mathrm{LG}$ variant $\mathrm{A}$ & $2.90 \pm 0.49$ & $3.02 \pm 0.49$ & 0.86 \\
\hline
\end{tabular}

${ }^{1}$ Least squares means expressed as value $\pm \mathrm{SE}$.

${ }^{2}$ Calculated as $[12.82 \times$ fat yield $(\mathrm{kg} / \mathrm{d})]+[7.13 \times$ protein yield $(\mathrm{kg} / \mathrm{d})]+[0.323 \times$ milk yield $(\mathrm{kg} / \mathrm{d})]$.

${ }^{3}$ Calculated as lactose yield $(\mathrm{kg} / \mathrm{d})+$ fat yield $(\mathrm{kg} / \mathrm{d})+$ protein yield $(\mathrm{kg} / \mathrm{d})$. 
$4^{\circ} \mathrm{C}$ and pooled within cow according to milk yield to create 1 representative sample per cow $(\mathrm{n}=16$ samples total). Of the milk samples retained for MFGM proteome analysis, 1 milk sample was excluded from processing due to improper storage. To the remaining 15 samples (8 GLH, 7 GLAH), a protease inhibitor cocktail (Sigma, Milwaukee, WI) was added at 0.24 $\mathrm{mL} / \mathrm{g}$ of protein. The MFGM was isolated according to previously published methods (Yang et al., 2015) with some modifications. Briefly, samples were centrifuged at $3,000 \times g$ at $4^{\circ} \mathrm{C}$ for $15 \mathrm{~min}$. The skim layer was discarded, and the cream layer was incubated with 5 volumes of phosphate-buffered saline at $37^{\circ} \mathrm{C}$ for 20 $\min$, followed by centrifugation at $3,000 \times g$ for $30 \mathrm{~min}$ at $4^{\circ} \mathrm{C}$. This wash and centrifugation step was repeated 3 times to remove residual $\mathrm{CN}$ proteins. The recovered cream was incubated with 10 volumes of lysis buffer [50 $\mathrm{m} M$ Tris- $\mathrm{HCl}$ at $\mathrm{pH} 7.4,4 \%$ SDS (wt/vol) solution] for $1 \mathrm{~h}$ at room temperature with periodic vortexing every 10 to $15 \mathrm{~min}$ for 10 to $15 \mathrm{~s}$. After incubation, samples were then placed in a water bath at $95^{\circ} \mathrm{C}$ for $5 \mathrm{~min}$ followed by centrifugation at $12,000 \times g$ at $4^{\circ} \mathrm{C}$ for 15 min. The residual fat was removed and lysates were centrifuged again. The lysates were then precipitated in acetone at a 1:6 ratio (lysate:acetone) at $-20^{\circ} \mathrm{C}$ for $20 \mathrm{~h}$. A universal control was generated before this step by pooling an equal volume of supernatant from each GLH sample. Following the precipitation, samples were centrifuged at $14,000 \times g$ at $4^{\circ} \mathrm{C}$ for $40 \mathrm{~min}$, and the pellet was resuspended in radioimmunoprecipitation assay buffer (Sigma-Aldrich, St. Louis, MO) to maximize protein suspension and concentration (Subedi et al., 2019) and protease inhibitor cocktail (Sigma) to inhibit degradation of suspended proteins followed by storage at $-80^{\circ} \mathrm{C}$ until protein quantification. The bicinchoninic acid assay (Pierce, Rockford, IL) was used to quantify protein concentrations with bovine serum albumin as the standard.

\section{SDS PAGE Separation of the MFGM-Associated Protein Fraction}

Quantified samples were separated by SDS-PAGE using a total of 2 gels. A random subset of 8 samples and a universal control were loaded on one gel, and a random subset of 7 samples and a universal control were loaded on the other. Reducing sample buffer $(5 \times$; Thermo Scientific, Rockford, IL) was added to each sample in a $1: 5$ ratio to $49 \mu \mathrm{g}$ of sample plus $1 \mu \mathrm{g}$ of Saccharomyces cerevisiae GAPDH (Sigma-Aldrich), and the mixture was heated at $90^{\circ} \mathrm{C}$ for $3 \mathrm{~min}$. The S. cerevisiae GAPDH was added to verify the efficiencies of subsequent digestion and TMT-labeling steps across samples. After cooling to room temperature, the samples were loaded onto a precast $12 \%$ polyacrylamide gel (Bio-Rad, Hercules, CA). Proteins were separated through electrophoresis, which was run for $15 \mathrm{~min}$ at 200 V. Gels were stained in Coomassie blue (Bio-Rad) overnight, and gel images were obtained from scanning before excision.

\section{In-Gel Digestion of the MFGM-Associated Protein Fraction}

The gel lanes were excised into 3 segments according to their molecular weights ( $\mathrm{I}=$ heavier in weight, upper portion of the gel; II = medium weight, middle portion of the gel; III = lighter in weight, lower portion of the gel; see Figure 1 for example of gel image and segmentation) and subjected to trypsin digestion protocols as described previously (Tacoma et al., 2016), except for using triethylammonium bicarbonate as buffer instead of ammonium bicarbonate. This gelbased separation strategy allowed the high-abundant proteins to be confined to gel slice II-mid, whereas the relatively low-abundant proteins were localized in gel slices I-upper and III-lower. Gel slices I, II, and III were each analyzed separately in $3 \mathrm{MS}$ runs to increase the proteome coverage.

\section{Isobaric TMT Labeling of the MFGM-Associated Protein Fraction}

Isobaric TMT labeling of the protein samples was performed according to the manufacturers' protocols with minor modifications. Briefly, dried peptides in gel slices I and III and gel slice II from each sample were resuspended in 25 and $50 \mu \mathrm{L}$ of triethylammonium bicarbonate, respectively. After resuspension, 10 and $20 \mu \mathrm{L}$ of TMT reagents $(0.8 \mathrm{mg}$ dissolved in $41 \mu \mathrm{L}$ of acetonitrile) were added to gel slices I and III and gel slice II, respectively, followed by brief vortexing and incubation for $1.5 \mathrm{~h}$ at room temperature. Then, $5 \%$ hydroxylamine was added to quench the reactions. Onethird of the total reactions was combined, resulting in three 9-plex reactions (I, II, III) from gel 1 (TMT-1) and three 8-plex reactions (I, II, III) from gel 2 (TMT2 ). The mixtures were dried and stored at $-80^{\circ} \mathrm{C}$ until LC-MS/MS analysis.

\section{LC-MS/MS}

The LC-MS/MS analysis was conducted as previously described (Tacoma et al., 2017b). Briefly, a Q-Exactive mass spectrometer coupled to an EASY-nLC (Thermo Fisher Scientific) was used for peptide identification and quantification. 


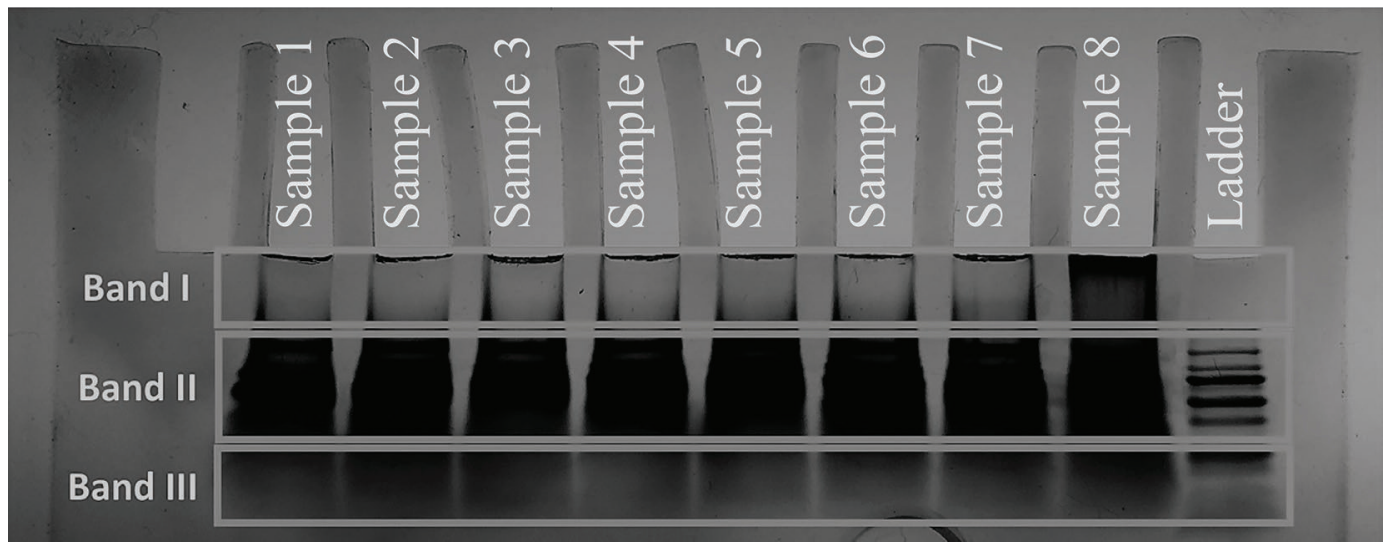

Figure 1. Gel image of samples (1 sample per lane) after protein separation by SDS-PAGE. After separation was complete, each lane was excised into 3 segments (depicted as bands I, II, and III), lanes were separated, and each segment from each lane was then analyzed separately by liquid chromatography-tandem MS.

The resulting product ion spectra were searched using the SEQUEST and Mascot search engines on Proteome Discoverer 2.2 (Thermo Fisher Scientific) against a curated Uniprot Bos taurus protein database (UP000009136; downloaded on Aug. 31, 2017). Common processing and consensus workflows for reporterbased quantification were used with minor modifications. In the processing workflow, the parameters were set as follows: (1) full trypsin enzymatic activity; (2) maximum missed cleavages $=2$; $(3)$ minimum peptide length $=6$, (4) mass tolerance at $10 \mathrm{ppm}$ for precursor ions and 0.02 Da for fragment ions; (5) dynamic modifications on methionines (+15.9949 Da: oxidation), dynamic TMT6plex modification (the TMT6plex and TMT10plex have the same isobaric mass) on N-termini and lysines (229.163 Da); and (6) static carbamidomethylation modification on cysteines $(+57.021 \mathrm{Da})$. Percolator node was included in the workflow to limit the false-positive rates to less than $1 \%$ in the data set.

In the consensus workflow, parameters were set as follows: (1) both unique and razor peptides were used for quantification; (2) reject quan results with missing channels: false; (3) apply quan value corrections: false; (4) co-isolation threshold: 50; (5) average reporter $\mathrm{S} / \mathrm{N}$ threshold $=10 ;(6)$ no normalization was used; and (7) scaling mode was set "on all average." The raw files of the 3 separate runs of MFGM fraction (I, II, and III) were searched together, resulting in 2 results files (TMT-1 for gel 1 and TMT-2 for gel 2). Protein identification and quantification information $(<1 \%$ false positive) were exported from the msf result files to Excel (Microsoft, Redmond, WA) spreadsheets. Only the proteins that were identified in both TMT-1 and TMT-2 runs were kept. The ratios (relative to the respective universal control in each TMT run) were used for further statistical analyses.

\section{Statistical and Bioinformatic Analysis}

For statistical analysis, PROC MIXED of SAS 9.4 (SAS Institute Inc., Cary, NC) was performed, including treatment (GLH vs. GLAH) as the fixed effect and milk parameter as the dependent variable. Treatment least squares means were compared using the probability of differences (PDIFF) option and included a Tukey adjustment test. Of the 76 proteins identified in the skim milk fraction and 367 proteins identified in the MFGM-associated fraction through Proteome Discoverer 2.2 (Thermo Fisher Scientific), 68 skim milk-associated proteins and 365 MFGM-associated proteins were present in enough samples to be statistically analyzed, and proteins that were included in statistical analysis were included in bioinformatic characterization. For bioinformatic analysis, proteins that were uncharacterized in Proteome Discoverer 2.2 (Thermo Fisher Scientific) were identified by obtaining their FASTA sequence through UniProt (Chen et al., 2017) and searching this sequence in BLAST (Camacho et al., 2009). Identified proteins were then annotated according to their biological processes, molecular functions, and cellular components through gene ontology (GO) using the PANTHER classification system (Mi et al., 2017). All GO data presented are the percentage of gene hits against the total number of genes identified. Statistical differences were declared significant if $P \leq$ 0.05 .

\section{RESULTS AND DISCUSSION}

In this study, the skim milk- and MFGM-associated milk proteomes produced by cows grazing GLH were compared with the proteomes produced by cows grazing GLAH pastures. From a production perspective, 
the altered pasture profile and nutrient density of the GLAH pasture did not result in higher milk or lactose yields but did support higher milk fat and protein secretion (both $\%$ and $\mathrm{kg} / \mathrm{d}$ ) from cows grazing this GLAH pasture, as outlined in Table 1. This resulted in a positive increase in milk solids (total sum of lactose, protein, and fat) and ECM yield $(\mathrm{kg} / \mathrm{d})$, and would generally be perceived as beneficial from a commercial standpoint and would be a result of increased mammary metabolism. Focusing on the high-abundance milk protein profile, the concentration of $\alpha_{\mathrm{S}_{1}} \mathrm{CN}$ was $18 \%$ higher $(P=0.005)$ in milk from cows grazing GLAH (mean $=14.4 \mathrm{mg} / \mathrm{mL})$ compared with those grazing GLH $($ mean $=12.2 \mathrm{mg} / \mathrm{mL}$; Table 1$)$, whereas there were no differences in $\alpha_{\mathrm{S}_{2}} \mathrm{CN}, \alpha-\mathrm{LA}, \beta-\mathrm{CN}, \kappa-\mathrm{CN}, \beta-\mathrm{LG}$ variant $A$, and $\beta$-LG variant $B$ concentrations across treatments (Table 1 ). The reason for this increase is not currently understood. A tentative hypothesis could be that the shift in $\alpha_{S 1}$ - CN may be a result of higher nutrient density in the GLAH, which contained greater concentrations of CP $(14.8 \%$ in GLAH vs. $12.9 \%$ in GLH) and starch (2.2\% in GLAH vs. $1.0 \%$ in GLH). Tacoma et al. (2017a) reported higher concentrations of $\kappa-\mathrm{CN}$ and a trend toward higher concentrations of $\mathrm{CN}$ isoforms $\alpha_{\mathrm{S} 1}$ and $\beta$ produced by the cows fed a diet containing $18.5 \% \mathrm{CP}$ (as \% of DM) that had a higher RDP:RUP ratio compared with Holstein cows fed an isonitrogenous diet that had a lower RDP:RUP ratio. The proportion of RDP:RUP was not measured in the current trial, and post-grazing botanical composition was not analyzed to determine whether cows were being selective of specific herbages species; however, the higher milk and plasma urea-N concentrations reported by Juntwait et al. (2016) from the cows grazing GLH compared with GLAH suggest that the total CP available was the more influential factor in this current trial.

To examine the proteomes associated with the skim milk- and MFGM-associated fractions, we used different techniques to isolate these groups of proteins from the milk samples collected. Using LC-MS/MS techniques to characterize the skim milk- and MFGM-associated protein fractions, 8 of the 433 proteins characterized $(1.8 \%)$ were identified at greater relative abundance from cows that were grazing GLAH compared with those grazing GLH (Table 2). Similar to protein identification rates in other studies using similar methods (e.g., Fahey et al., 2020), a total of 76 proteins were identified in the low-abundance protein-enriched skim milk fraction, and 68 were included in statistical analysis (Supplemental Table S1, https://doi.org/10.3168/ jds.2019-17726). Whereas 66 of these proteins were not affected by dietary treatment, 2 of these proteins were higher in milk from cows grazing GLAH compared with the GLH cows (Table 2), including $\beta$-2-microglobulin
$(P=0.009)$ and polymeric immunoglobulin receptor $(P=0.04)$. The protein 2 -microglobulin is a component associated with the major histocompatibility complex I and has been detected in all body fluids as well as the surfaces of nucleated cells (Bourantas et al., 1999). Little information outlining the functionality of 2-microglobulin in milk has been reported, and the effect of diet on this protein is not understood; however, it is a component of the receptor responsible for IgG transfer across mammary epithelial cells, and polymorphisms of the gene coding for this protein result in suppression of IgG1 secretion in milk (Zhao et al., 2012). Polymeric immunoglobulin receptor is another immune-related protein that is associated with $\operatorname{IgA}$ production in the small intestine (Asano and Komiyama, 2011). A more extensive gel (SDS-PAGE)-based fractionation protocol was included to increase the separation and identification of proteins in the MFGM, resulting in identification of a total of 367 proteins in the MFGM-associated protein fraction, 365 of which were included in statistical analysis (Supplemental Table S2, https://doi .org/10.3168/jds.2019-17726). The number of proteins identified in the current trial is less than the published work by Yang et al. (2015), who used a similar MFGM isolation technique but used a non-gel-based iTRAQ downstream protocol. In the current research, only 6 proteins identified in the MFGM fraction were different $(P \leq 0.05)$ in abundance across cows grazing GLH versus GLAH: acetyl-CoA carboxylase 1, aminopeptidase, mucin-16 isoform X4, volume regulated anion channel subunit LRRC8C, elongation factor 2, and oncostatinM-specific receptor subunit $\beta$ precursor. All of these proteins were higher in relative abundance within the MFGM-associated protein fraction from animals grazing GLAH compared with those grazing GLH (Table 2 ). Some of these proteins have known associations with mammary gland function and, in particular, milk fat synthesis. Although we did not measure indicators of milk fat synthesis shifts such as fatty acid profile or mammary gene expression as part of the experiment presented herein, milk fat (\% and concentration) was higher in samples from cows grazing GLAH compared with samples from those grazing GLH, suggesting a shift in fatty acid metabolism within the mammary gland, and could include a combination of uptake, passage, and synthesis. Acetyl-CoA carboxylase is an important enzyme in mammary de novo fatty acid synthesis, and the coding region of the acetyl-CoA carboxylase gene (ACACA) has been proposed to be an important candidate gene to estimate milk fat content (Bionaz and Loor, 2008; Matsumoto et al., 2012). Acetyl-CoA carboxylase 1, mucin-16, and leucine-rich repeat-containing protein $8 \mathrm{C}$ (which was the predicted protein corresponding to accession A5PK13, which is 
now identified as volume regulated anion channel subunit LRRC8C) were all previously reported to be present at higher abundance in the proteome surrounding small milk fat globules compared with the proteome surrounding large globules (Lu et al., 2016). All cows used in this study were the Jersey breed; however, it is interesting to note that Jersey cattle have small milk fat globule sizes compared with some other breeds such as Holsteins (Fleming et al., 2017), and hence globule size-associated proteins may be more responsive in the Jersey breed of cows. Although the literature outlining the importance of oncostatin-M receptor proteins in milk is limited, changes in milk fatty acid profile and milk fat synthesis in dairy cattle as a result of linseed or safflower oil supplementation did induce a shift in mammary mRNA expression of oncostatin-M receptor (Ibeagha-Awemu et al., 2016), suggesting at least some interaction between diet and this protein at the mammary level.

Apart from examination of the implications of pasture plant species on protein profile, this study examined the skim milk proteome alongside the MFGM-associated proteome and allowed for more extensive comparative analysis of the comprehensive proteome. In this experiment, a total of 68 proteins were characterized in the skim milk fraction and 365 proteins were characterized in the MFGM-associated protein fraction. Furthermore, of the proteins identified by LC-MS/MS analysis in the skim milk- and MFGM-associated protein fractions, 34 proteins were identified in both fractions (Table 3 ). Much of this overlap is likely a result of the inability of the methodology to purely isolate the 2 fractions from each other as well as the biological origins of the fractions themselves. For instance, cytosolic crescents trapped within a milk fat droplet would likely include many cellular proteins that would be more highly abundant in the skim milk fraction due to cell sloughing, whereas the milk skimming protocol would likely leave a small amount of fat residue in the sample as well as lysed MFGM fragments. Although it is important to be mindful of these limitations, overall trends of the overlapping proteins may still be worthwhile to consider. Two keratin proteins (A6ANZ7 and G3N0V2) that have AA sequences that are similar across both humans and cattle are within this list and could be a result of keratin shedding by the mammary gland (Bitman et al., 1991) or some human contamination, which is commonly observed across proteomic studies. Apart from keratin, the other 32 proteins highlight some potentially interesting biology. Within this list of proteins identified across the 2 proteomes, both of the skim milk proteins affected by diet were included, and patterns of these 2 proteins in the MFGM followed the same numeric trend across treatment, though not significant. However, none of the MFGM-associated proteins affected by diet were identified in the skim milk proteome, suggesting some deviation in functionality across the 2 proteomes despite an overall similar pattern in the functionality profiles as GO revealed through PANTHER (Figure 2).

Nutrient profile of the pasture could also be driving the higher relative abundance of these low-abundance proteins in the milk from cows grazing GLAH compared with those grazing GLH; however, the lack of uniform increase across the whole proteome suggests that perhaps biological function, rather than simply dietary nutrient density, may also be an important consideration. Although milk itself is not a connected tissue, and the parent mammary gland is a somewhat unique tissue in and of itself, use of GO analysis to characterize the identified milk proteomes can be a useful mechanism to gain a sense of the effect of treatment on the secreted milk protein profile in terms of the likely origin and function of the protein in the dam, or perhaps its bioactive potential post-consumption. Cellular process (GO term: 0009987) was the most annotated term for biological process across both the skim milk- and MFGM-associated protein fractions,

Table 2. Proteins affected by diet as identified by liquid chromatography-tandem MS analysis in the skim milk fraction and milk fat globule membrane (MFGM)-associated protein fraction in cows that grazed either grass-legume herbage (GLH) or pastures that included GLH plus annual forage crops $(\mathrm{GLAH})$

\begin{tabular}{|c|c|c|c|c|c|}
\hline \multirow[b]{2}{*}{ Fraction } & \multirow[b]{2}{*}{ Accession } & \multirow[b]{2}{*}{ Protein name } & \multicolumn{2}{|c|}{ Diet $^{1}$} & \multirow[b]{2}{*}{$P$-value } \\
\hline & & & GLH & GLAH & \\
\hline Skim milk & P81265 & Polymeric immunoglobulin receptor & $1.35 \pm 0.37$ & $2.56 \pm 0.37$ & 0.04 \\
\hline \multirow[t]{4}{*}{ MFGM } & E1BGH6 & Acetyl-CoA carboxylase 1 & $0.86 \pm 0.09$ & $1.21 \pm 0.08$ & 0.01 \\
\hline & E1BP91 & Aminopeptidase & $0.77 \pm 0.09$ & $1.13 \pm 0.09$ & 0.01 \\
\hline & G3MXR2 & Mucin-16 isoform X4 & $0.84 \pm 0.06$ & $1.07 \pm 0.06$ & 0.03 \\
\hline & F1MGK8 & Oncostatin-M-specific receptor subunit $\beta$ precursor & $0.99 \pm 0.10$ & $1.29 \pm 0.09$ & 0.05 \\
\hline
\end{tabular}

${ }^{1}$ Least squares means expressed as abundance relative to the universal control \pm SE. 
being annotated to 22.7 and $40.9 \%$ of the proteins identified in the skim milk- and MFGM-associated protein fractions, respectively (Figure 2A). A recent milk proteomics review (Greenwood and Honan, 2019) included a small meta-analysis using several data sets to compare the skim milk and MFGM proteomes and identified the majority of proteins from both proteomes as being involved in cellular process. Whereas the review reported similar annotation proportion for the skim milk proteome, with a range of 21.7 to $29.0 \%$ of identified proteins being annotated to cellular process in the data sets used, the review reported that cellular process annotation comprised only 24.2 to $28.2 \%$ of the MFGM-associated proteome, which is lower than that observed in the current trial. This could again be a result of breed or globule size or could be due to differences in methodology, which are noted by Greenwood and Honan (2019) as a likely source of variation across proteomic research. In the current trial, response to stimulus (GO term: 0050896), localization (GO term: 0051179), biological regulation (GO term: 0065007), and metabolic process (GO term: 0008152) proceeded cellular process for both the skim milk- and MFGMassociated proteins. Catalytic activity (GO term: 0003824) and binding (GO term: 0005488) were the most annotated molecular function terms for the skim milk and MFGM proteins, accounting for a combined total of 48.5 and $61.6 \%$ in the skim fraction and MFGM fraction, respectively (Figure 2B). The GO classification of catalytic activity encompasses enzymes, whereas the classification of binding encompasses receptors and other proteins that possess a binding site. Given the highly metabolic nature of the mammary gland and its reliance on nutrient uptake from the blood, it is not surprising to identify a high proportion of these protein classes within the milk proteome, which includes proteins secreted through numerous routes. There were a few examples of divergence in GO terms for both proteomes. Additional molecular function terms that were annotated for MFGM proteins and not the skim proteins included structural molecule activity (GO term: 0005198), translation regulator activity (GO term: 0005198), and transporter activity (GO term: 0005215). Although the higher number of classifications

Table 3. The 34 common proteins identified by liquid chromatography-tandem MS analysis in both the skim milk- and milk fat globule membrane-associated protein fractions from cows that grazed either grass-legume herbage or pastures that included grass-legume herbage plus annual forage crops

\begin{tabular}{|c|c|}
\hline Accession & Protein \\
\hline A0A140T897 & Serum albumin \\
\hline A0A140T8A9 & $\kappa$-Casein \\
\hline A0JNP2 & Secretoglobin family 1D member \\
\hline A5PJE3 & Fibrinogen $\alpha$ chain \\
\hline A6QNL0 & Monocyte differentiation antigen CD14 \\
\hline A6QNZ7 & Keratin 10 (epidermolytic hyperkeratosis; keratosis palmaris et plantaris) \\
\hline F1MUT3 & Xanthine dehydrogenase/oxidase \\
\hline F1MXX6 & Lactadherin \\
\hline F1N1N6 & Perilipin \\
\hline F1N726 & Glycoprotein 2 \\
\hline G3MXB5 & Immunoglobulin IgA heavy chain constant region, partial \\
\hline G3N0S9 & Predicted: apolipoprotein $\mathrm{R}$ \\
\hline G3N0V2 & Keratin 1 \\
\hline G5E513 & IgM heavy chain constant region, secretory form, partial \\
\hline G5E5H7 & Progestagen associated endometrial protein \\
\hline G5E5T5 & Immunoglobulin M heavy chain secretory form \\
\hline P00711 & $\alpha$-Lactalbumin \\
\hline P01888 & $\beta$-2-Microglobulin \\
\hline P02662 & $\alpha_{S 1}-$ Casein \\
\hline P02663 & $\alpha_{\mathrm{S} 2}$-Casein \\
\hline P02666 & $\beta$-Casein \\
\hline P08037 & $\beta-1,4$-Galactosyltransferase 1 \\
\hline P10790 & Fatty acid-binding protein, heart \\
\hline P11151 & Lipoprotein lipase \\
\hline P15497 & Apolipoprotein A-I \\
\hline $\mathrm{P} 18892$ & Butyrophilin subfamily 1 member A1 \\
\hline P24627 & Lactotransferrin \\
\hline P26201 & Platelet glycoprotein 4 \\
\hline P80025 & Lactoperoxidase \\
\hline P80195 & Glycosylation-dependent cell adhesion molecule 1 \\
\hline P81265 & Polymeric immunoglobulin receptor \\
\hline Q28065 & C4b-binding protein $\alpha$ chain \\
\hline Q32PA1 & CD59 molecule (CD59 blood group) \\
\hline Q9MZ06 & Fibroblast growth factor-binding protein 1 \\
\hline
\end{tabular}


$\mathbf{A}$

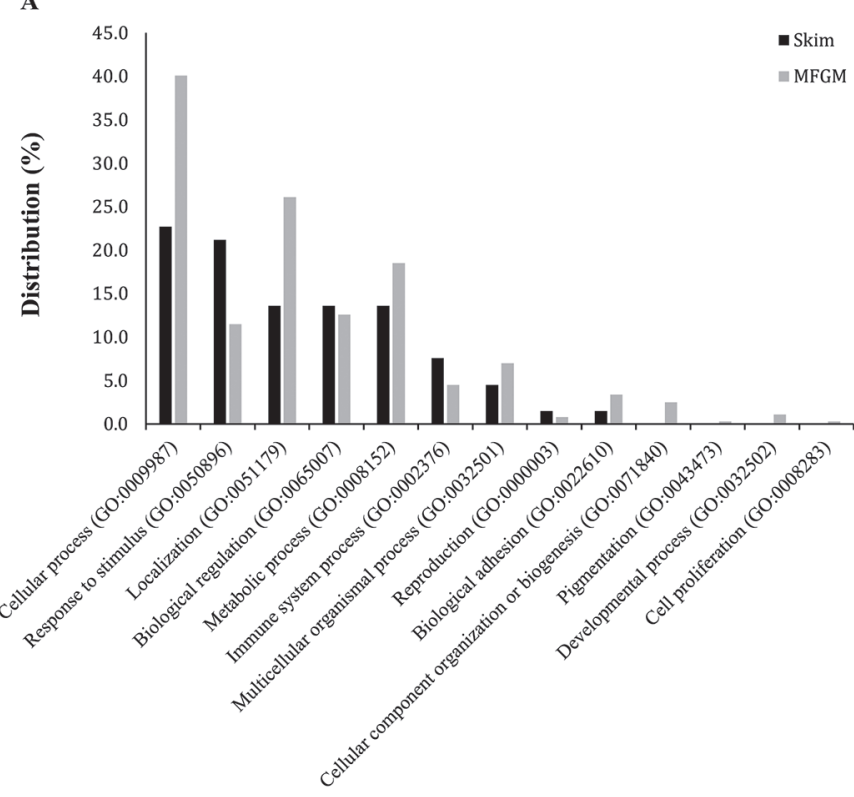

B

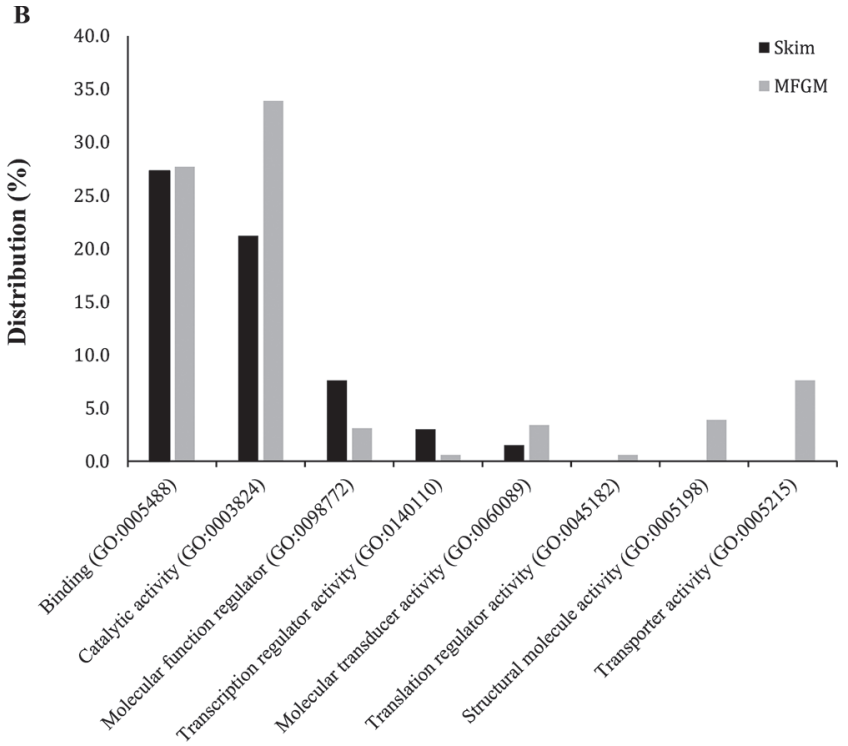

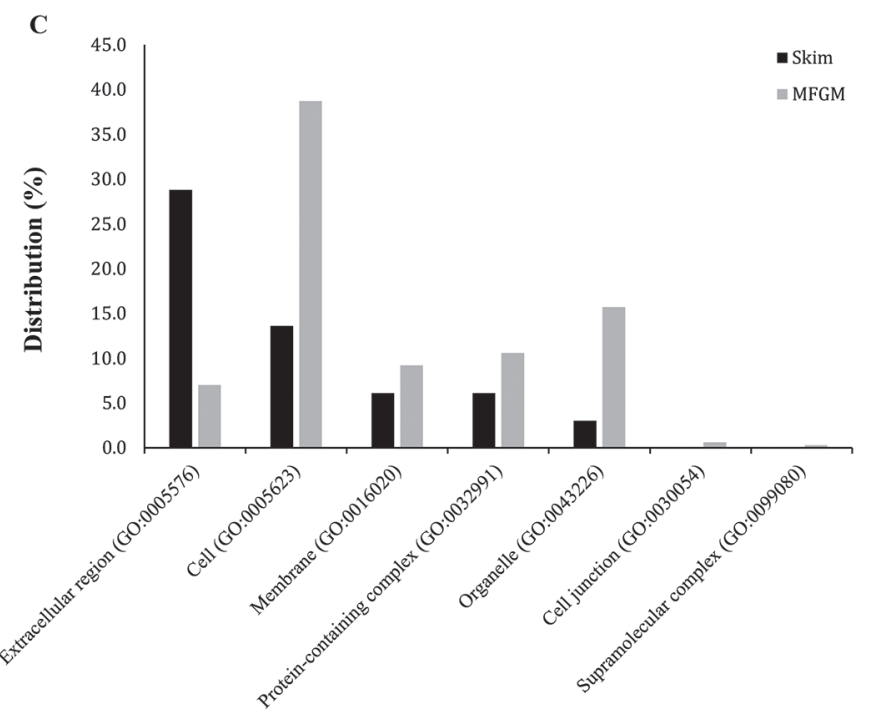

Figure 2. The gene ontology (GO) annotations of the proteins identified by liquid chromatography-tandem MS analysis in both skim milk and milk fat globule membrane (MFGM) samples according to their (A) biological process, (B) molecular function, and (C) cell component.

identified in the MFGM is likely due to the greater number of proteins identified within that proteome, comparison of the profiles of the identified proteins across the 2 proteomes (Figure 2) highlights that the skim milk proteome contained a greater proportion of proteins associated with response to stimulus, biological regulation, immune system process, and reproduction compared with the MFGM. Research exploring the bioactive properties of immune-associated proteins in milk has been at the forefront of scientific progress in the field of milk proteomics because of milk's important contribution to neonatal immunity, and the research herein affirms that the skim milk portion of milk may contain the higher number of immune-associated proteins for further study, though potency cannot be elucidated from this study. An interactomics-based study from Zhang et al. (2016) highlighted changes throughout lactation in human and bovine milk samples in both the skim and MFGM fractions, and GO analysis similarly revealed a larger proportion of proteins associated with immune-related activity in the skim milk protein fraction in both human and bovine samples compared with the MFGM fraction. In contrast, under the biological process annotations, many proteins with cell-associated process classifications were identified in higher proportions in the MFGM-associated proteome. 
As expected, the skim milk and MFGM-associated proteomes were different in their cellular component profiles. According to cellular component annotation of the skim milk protein fraction, $28.8 \%$ were annotated with the extracellular region (GO term: 0005576) followed by cell (13.6\%; GO term: 0005623), membrane (6.1\%; GO term: 0016020), and protein-containing complex (6.1\%; GO term: 0032991; Figure 2C). In contrast, more than $50 \%$ of the MFGM proteins were annotated as cell or organelle associated, which is consistent with the literature outlining the formation of the MFGM itself (Cavaletto et al., 2008). The MFGM cellular component annotation included $38.7 \%$ of proteins as being from the cell (GO term: 0005623), followed by $15.7 \%$ being organelle associated (GO term: 0043226 ) and $15.7 \%$ being part of a protein-containing complex (GO term: 0032991). The higher inclusion of these protein classes in the MFGM-associated proteome is likely also a result of its inclusion of the apical membrane acquired during secretion and is in line with previous observations (Greenwood and Honan, 2019). Additional cellular component terms that were annotated for the MFGM-associated protein fraction, but not the skim milk fraction, included the cell junction (GO term: 0030054) and supramolecular complex (GO term: 0099080). This could be a result of simply having a higher protein number identified using a more intensive fractionation methodology, as biologically it would seem likely to identify proteins of these classes in both the skim milk and MFGM fractions. Despite the differences observed in cellular component annotation between the skim milk and MFGM fractions, membrane proteins (GO term: 0016020) were identified to be present at similar proportions in both skim milk and MFGM fractions (6.1 and 9.2\%, respectively), again highlighting the complexity of interpreting these unique yet complimentary proteomes.

\section{CONCLUSIONS}

In this experiment, the inclusion of AFC in pasture affected $1.8 \%$ of the skim milk and MFGM proteomes, which may be related to the low proportion of AFC in the pasture or change in overall nutritional value of the feed. Of the proteins that were affected by diet, both of the proteins affected in the skim milk fraction are involved in immune function, whereas many of the 8 MFGM-associated proteins have roles in mammary cell function and milk fat synthesis or secretion. On a comparative level, bioinformatics examination of proteome associated with the skim milk fraction and MFGM fraction highlighted some potential differences in pre-secretory cellular localization of the proteins as well as known current roles of the proteins within the characterized proteomes. This trial and results reported herein provide support to mounting evidence that diet can, at least to some extent, alter the bovine milk proteome and that the different fractions of milk (namely, the skim- and MFGM-associated fractions) are unique in their proteome profiles.

\section{ACKNOWLEDGMENTS}

The authors thank K. Juntwait (University of New Hampshire, Durham) and the staff at The University of New Hampshire's Burley-Demeritt Organic Dairy Research Farm (Lee) for overall research support and animal care feeding study. Additional thanks are extended to the University of Vermont Biostatistics Unit (Burlington) for assistance with statistical analysis. The authors acknowledge funding from the USDA National Institute of Food and Agriculture (Washington, DC) Hatch grant number VT-H02009. The Vermont Genetics Network Proteomics Facility (Burlington) is financially supported by National Institutes of Health (Bethesda, MD) grant P20GM103449 from the INBRE Program of the National Institute of General Medical Sciences (Bethesda, MD). Equipment used in this experiment included pieces funded by National Institutes of Health grant numbers 5 P30 RR032135 from the COBRE Program of the National Center for Research Resources (Bethesda, MD) and 8 P30 GM 103498 from the National Institute of General Medical Sciences. We further thank the New Hampshire Agricultural Experiment Station (Durham, NH) for partially funding this study. This work was also supported by Northeast SARE (award number LNE13-323) and Hatch Multistate NC-2042 (project number NH00616-R; project accession number 1001855). The authors have not stated any conflicts of interest.

\section{REFERENCES}

Asano, M., and K. Komiyama. 2011. Polymeric immunoglobulin receptor. J. Oral Sci. 53:147-156. https://doi.org/10.2334/josnusd .53 .147 .

Bionaz, M., and J. J. Loor. 2008. Gene networks driving bovine milk fat synthesis during the lactation cycle. BMC Genomics 9:366. https: //doi.org/10.1186/1471-2164-9-366.

Bitman, J., D. L. Wood, S. A. Bright, R. H. Miller, A. V. Capuco, A. Roche, and J. W. Pankey. 1991. Lipid composition of teat canal keratin collected before and after milking from Holstein and Jersey cows. J. Dairy Sci. 74:414-420. https://doi.org/10.3168/jds.S0022 -0302(91)78184-8.

Bourantas, K. L., E. C. Hatzimichael, A. C. Makis, A. Chaidos, E. D. Kapsali, S. Tsiara, and A. Mavridis. 1999. Serum beta-2-microglobulin, TNF-alpha and interleukins in myeloproliferative disorders. Eur. J. Haematol. 63:19-25. https://doi.org/10.1111/j.1600 -0609.1999.tb01845.x.

Bryant, R. H., B. G. Welten, D. Costall, P. R. Shorten, and G. R. Edwards. 2018. Milk yield and urinary-nitrogen excretion of dairy cows grazing forb pasture mixtures designed to reduce nitrogen 
leaching. Livest. Sci. 209:46-53. https://doi.org/10.1016/j.livsci 2018.01.009.

Camacho, C., G. Coulouris, V. Avagyan, N. Ma, J. Papadopoulos, K. Bealer, and T. L. Madden. 2009. BLAST+: Architecture and applications. BMC Bioinformatics 10:421. https://doi.org/10.1186/ 1471-2105-10-421.

Cavaletto, M., M. G. Giuffrida, and A. Conti. 2008. Milk fat globule membrane components-A proteomic approach. Adv. Exp. Med. Biol. 606:129-141. https://doi.org/10.1007/978-0-387-74087-4_4.

Chen, C., H. Huang, and C. H. Wu. 2017. Protein bioinformatics databases and resources methods. Methods Mol. Biol. 1558:3-39. https: //doi.org/10.1007/978-1-4939-6783-4_1.

Christian, M. P., C. Grainger, B. J. Sutherland, J. J. Mayes, M. C. Hannah, and B. Kefford. 1999. Managing diet quality for cheddar cheese manufacturing milk. 1. The influence of protein energy supplements. J. Dairy Res. 66:341-355. https://doi.org/10.1017/ S0022029999003647.

D'Amato, A., A. Bachi, E. Fasoli, E. Boschetti, G. Peltre, H. Senechal, and P. G. Righetti. 2009. In-depth exploration of cow's whey proteome via combinatorial peptide ligand libraries. J. Proteome Res. 8:3925-3936. https://doi.org/10.1021/pr900221x.

Demmelmair, H., C. Prell, N. Timby, and B. Lönnerdal. 2017. Benefits of lactoferrin, osteopontin and milk fat globule membranes for infants. Nutrients 9:E817. https://doi.org/10.3390/nu9080817.

Fahey, M. J., A. J. Fischer, M. A. Steele, and S. L. Greenwood. 2020. Characterization of the colostrum and transition milk proteomes from primiparous and multiparous Holstein dairy cows. J. Dairy Sci. 103:1993-2005. https://doi.org/10.3168/jds.2019-17094.

Fleming, A., F. S. Schenkel, J. Chen, F. Malchiodi, R. A. Ali, B. Mallard, M. Sargolzaei, M. Corredig, and F. Miglior. 2017. Variation in fat globule size in bovine milk and its prediction using mid-infrared spectroscopy. J. Dairy Sci. 100:1640-1649. https://doi.org/ 10.3168/jds.2016-11427.

Greenwood, S. L., and M. C. Honan. 2019. Symposium review: Characterization of the bovine milk protein profile using proteomic techniques. J. Dairy Sci. 102:2796-2806. https://doi.org/10.3168/ jds.2018-15266.

Ibeagha-Awemu, E. M., R. Li, A. A. Ammah, P.-L. Dudemaine, N. Bissonnette, C. Benchaar, and X. Zhao. 2016. Transcriptome adaptation of the bovine mammary gland to diets rich in unsaturated fatty acids shows greater impact of linseed oil over safflower oil on gene expression and metabolic pathways. BMC Genomics 17:104. https://doi.org/10.1186/s12864-016-2423-X.

Juntwait, K. A., A. F. Brito, K. S. O'Connor, R. G. Smith, K. M. Aragona, and A. B. Pereira. 2016. Feeding annual forage crops to organic dairy cows during the spring and summer seasons in Northeast United States. Org. Agric. Res. Symp., Pacific Grove, CA. https://eorganic.info/sites/eorganic.info/files/u27/3.2.1 -Juntwait\%20et\%20al_Revised\%20Version_UNH-final.pdf.

Lee, H., E. Padhi, Y. Hasegawa, J. Larke, M. Parenti, A. Wang, O. Hernell, B. Lönnerdal, and C. Slupsky. 2018. Compositional dynamics of the milk fat globule and its role in infant development. Front Pediatr. 6:313. https://doi.org/10.3389/fped.2018.00313.

Lu, J., N. Argov-Argaman, J. Anggrek, S. Boeren, T. van Hooijdonk, F. Vervoort, and K. A. Hettinga. 2016. The protein and lipid composition of the membrane of milk fat globules depends on their size. J. Dairy Sci. 99:4726-4738. https://doi.org/10.3168/jds.2015 -10375 .

Matsumoto, H., K. Sasaki, T. Bessho, E. Kobayashi, T. Abe, S. Sasazaki, K. Oyama, and H. Mannen. 2012. The SNPs in the ACACA gene are effective on fatty acid composition in Holstein milk. Mol. Biol. Rep. 39:8637-8644. https://doi.org/10.1007/s11033-012 $-1718-5$.

Mi, H., X. Huang, A. Muruganujan, H. Tang, C. Mills, D. Kang, and P. D. Thomas. 2017. PANTHER version 11: Expanded annotation data from Gene Ontology and Reactome pathways, and data analysis tool enhancements. Nucleic Acids Res. 45(D1):D183-D189. https://doi.org/10.1093/nar/gkw1138.
Scuderi, R. A., D. B. Ebenstein, Y.-W. Lam, J. Kraft, and S. L. Greenwood. 2019. Inclusion of grape marc in dairy cattle rations alters the bovine milk proteome. J. Dairy Res. 86:154-161. https://doi .org/10.1017/S0022029919000372.

Shennan, D. B., and M. Peaker. 2000. Transport of milk constituents by the mammary gland. Physiol. Rev. 80:925-951. https://doi.org/ 10.1152/physrev.2000.80.3.925.

Stelwagen, K., and K. Singh. 2014. The role of tight junctions in mammary gland function. J. Mammary Gland Biol. Neoplasia 19:131138. https://doi.org/10.1007/s10911-013-9309-1.

Subedi, P., M. Schneider, J. Philipp, O. Azimzadeh, F. Metzger, S. Moertl, M. J. Atkinson, and S. Tapio. 2019. Comparison of methods to isolate proteins from extracellular vesicles for mass spectrometry-based proteomic analysis. Anal. Biochem. 584:113390. https://doi.org/10.1016/j.ab.2019.113390.

Tacoma, R., J. Fields, D. B. Ebenstein, Y.-W. Lam, and S. L. Greenwood. 2016. Characterization of the bovine milk proteome in earlylactation Holstein and Jersey breeds of dairy cows. J. Proteomics 130:200-210. https://doi.org/10.1016/j.jprot.2015.09.024.

Tacoma, R. J. Fields, D. B. Ebenstein, Y. W. Lam, and S. L. Greenwood. 2017a. Ratio of dietary rumen degradable protein to rumen undegradable protein affects nitrogen partitioning but does not affect the bovine milk proteome produced by mid-lactation Holstein dairy cows. J. Dairy Sci. 100:7246-7261. https://doi.org/10.3168/ jds.2017-12647.

Tacoma, R., S. L. Gelsinger, Y. W. Lam, R. A. Scuderi, D. B. Ebenstein, A. J. Heinrichs, and S. L. Greenwood. 2017b. Exploration of the bovine colostrum proteome and effects of heat treatment time on colostrum protein profile. J. Dairy Sci. 100:9392-9401. https:// doi.org/10.3168/jds.2017-13211.

Totty, V. K., S. L. Greenwood, R. H. Bryant, and G. R. Edwards. 2013. Nitrogen partitioning and milk production of dairy cows grazing simple and diverse pastures. J. Dairy Sci. 96:141-149. https://doi.org/10.3168/jds.2012-5504.

Vargas-Bello-Pérez, E., R. I. Márquez-Hernández, and L. E. Hernández-Castellano. 2019. Bioactive peptides from milk: Animal determinants and their implications in human health. J. Dairy Res. 86:136-144. https://doi.org/10.1017/S0022029919000384.

Wall, S. K., J. J. Gross, E. C. Kessler, K. Villez, and R. M. Bruckmaier. 2015. Blood-derived proteins in milk at start of lactation: Indicators of active or passive transfer. J. Dairy Sci. 98:7748-7756. https://doi.org/10.3168/jds.2015-9440.

Wellnitz, O., C. Zbinden, X. Huang, and R. M. Bruckmaier. 2016. Short communication: Differential loss of bovine mammary epithelial barrier integrity in response to lipopolysaccharide and lipoteichoic acid. J. Dairy Sci. 99:4851-4856. https://doi.org/10.3168/ jds.2016-10927.

Yang, Y., N. Zheng, X. Zhao, Y. Zhang, R. Han, L. Ma, S. Zhao, S. $\mathrm{Li}, \mathrm{T}$. Guo, and J. Wang. 2015. Proteomic characterization and comparison of mammalian milk fat globule proteomes by iTRAQ analysis. J. Proteomics 116:34-43. https://doi.org/10.1016/j.jprot .2014.12.017.

Zhang, L., A. D. van Dijk, and K. Hettinga. 2016. An interactomics overview of the human and bovine milk proteome over lactation. Proteome Sci. 15:1. https://doi.org/10.1186/s12953-016-0110-0.

Zhao, S., G. Liu, J. Wang, C. Zhang, D. Bu, K. Liu, and L. Zhou. 2012. Short communication: Association of polymorphisms of beta-2-microglobulin gene $(32 \mathrm{~m})$ with milk IgG1 content in Chinese Holstein cows. Livest. Sci. 143:289-292. https://doi.org/10.1016/j .livsci.2011.10.004.

\section{ORCIDS}

A. F. Brito ๑ https://orcid.org/0000-0003-3209-5473

S. L. Greenwood ๑ https://orcid.org/0000-0003-0654-6103 